\title{
Judean Merchants in Babylonia and Their Participation in Long-Distance Trade
}

\author{
Alstola, Tero
}

2017-06

Alstola , T 2017 , ' Judean Merchants in Babylonia and Their Participation in Long-Distance

Trade ' , Welt des Orients, vol. 47 , no. 1 , pp. 25-51 . https://doi.org/10.13109/wdor.2017.47.1.25

http://hdl.handle.net/10138/232512

https://doi.org/10.13109/wdor.2017.47.1.25

publishedVersion

Downloaded from Helda, University of Helsinki institutional repository.

This is an electronic reprint of the original article.

This reprint may differ from the original in pagination and typographic detail.

Please cite the original version. 


\title{
Judean Merchants in Babylonia and Their Participation in Long-Distance Trade ${ }^{1}$
}

\author{
Tero Alstola
}

\section{Summary}

This article focuses on Judean merchants in Babylonia, their social networks, and their business activities in the sixth century BCE. I argue that these people were integrated into the commercial sphere of Babylonian society and that they had native Babylonian merchants as well as traders of foreign origin among their acquaintances. Judeans participated in Babylonian long-distance trade, and documented evidence shows that some of them travelled as far as Iran for the purpose of trading. Furthermore, because travelling and the transportation of goods are an integral part of commercial activity, merchants provide an example of people who could have maintained connections between Judeans living in Judah and Babylonia.

Nebuchadnezzar II's campaigns against Judah resulted in the resettlement of a considerable number of Judeans in Babylonia in the early sixth century BCE. According to the Hebrew Bible, Judeans in Judah and Babylonia remained in touch with each other after the deportations. Jeremiah 29 describes how letters were sent from Judah to Babylonia and back, and, later in chapter 51, Jeremiah writes prophecies against Babylon on a scroll that would be sent with a Judean royal official to Babylon. Ezekiel 33:21-22 refers to a Judean refugee who brings the news about the destruction of Jerusalem to the exiles. Whatever the historicity of these accounts, it is interesting that their ancient authors take the possibility of communicating between Judah and Babylonia for granted.

Later in the first millennium CE, the exchange of thoughts, goods, and people between the Jewish communities in Palestine and Babylonia is well documented. ${ }^{2}$ These contacts were not only driven by social and religious concerns but also by commercial ambitions, and Jewish businessmen engaged in

1 This article has been written in the framework of the ERC Starting Grant project "By the Rivers of Babylon: New Perspectives on Second Temple Judaism from Cuneiform Texts" (PI Caroline Waerzeggers). The research for this article has also been supported by the Academy of Finland Centre of Excellence in "Changes in Sacred Texts and Traditions" (PI Martti Nissinen). I wish to thank the Trustees of the British Museum for their kind permission to study and cite from tablets in their care. I am grateful to Caroline Waerzeggers, Martti Nissinen, Collin Cornell, the anonymous reviewer of this article, and the participants of the "Assyriology and the Bible" session at the SBL Annual Meeting in 2014 for their helpful suggestions in various stages of preparing this article. All shortcomings of course remain my own.

2 See Oppenheimer 2005, 417-32; Hezser 2011, 311-64. 
trade along the Silk Road. ${ }^{3}$ However, long-distance trade between the Eastern Mediterranean and Babylonia flourished already a millennium earlier in the Neo-Babylonian period. Babylonia had fertile soil, but it was poor in natural resources, which had to be obtained by means of tribute, taxes, and trade. Metal, wood, and luxury items were imported from different parts of the Near East, which offered opportunities for traders of non-Babylonian descent. ${ }^{4}$ The present article shows that Judeans also participated in Babylonian long-distance trade in the sixth century BCE and that their trading missions might well have reached Judah.

The Hebrew Bible offers scanty information on the life of Judeans in Babylonia. At the same time, the cuneiform documents on Judeans cover the period from the early sixth century until the late fifth century BCE, and they are thus the main source for any social-historical study of Judeans in Babylonia. The majority of Babylonian sources on Judeans originate from the countryside, the most important text groups being the documents from the surroundings of (Āl-)Yāhūdu ${ }^{5}$ and the Murašû archive. ${ }^{6}$ Some Judeans lived in Babylonian cities: texts from the palace archive of Nebuchadnezzar II shed light on the fate of the Judean king Jehoiachin and his family, ${ }^{7}$ and Judean merchants are attested in several texts from Sippar. ${ }^{8}$ Because Babylonian sources rarely make the ethnic origin of people explicit, onomastic analysis is the primary method to identify Judeans in cuneiform texts. The use of the Yahwistic theophoric element is the most distinctive feature of Judean personal names, and some other names such as Amušê (Hosea) appear to be exclusively Judean. ${ }^{9}$ However, most non-theophoric West Semitic names do not reveal the geographic or ethnic background of their bearer, and the adoption of Babylonian names further complicates attempts to identify people of Judean origin. A significant number of Judeans in Babylonian sources thus remain unidentified.

This article focuses on Judean merchants in Babylonia, their social networks, and their business activities. I argue that these people were integrated into the commercial sphere of Babylonian society and that they had native Babylonian merchants as well as traders of foreign origin among their acquaintances. Fur-

3 Utas 1993, 27-28; Dignas and Winter 2007, 208-9; Hezser 2011, 325-32.

4 On Babylonian long-distance trade, see Oppenheim 1967, 236-54; Graslin-Thomé 2009.

5 Pearce and Wunsch 2014. One should be cautious not to use the term "Āl-Yāhūdu texts", because the documents from the village of (Āl-)Yāhūdu comprise only a part of the whole text corpus. Additionally, although the name has been usually transcribed as Āl-Yāhūdu, "town of Judah", a more accurate transcription of uru $i a-h u-d u$ might simply be "Yāhūdu." The sign uru probably represents the determinative for towns and is not an independent word. I use the name Yāhūdu in this article. See Zadok 2015, 142; Waerzeggers 2015, 179.

6 On the Murašu archive in general, see Stolper 1985. On Judeans in the archive, see Zadok 1979; Zadok 2002.

7 Weidner 1939, 923-35; Pedersén 2005b, 267-72.

8 Bloch 2014, 119-72.

9 On Yahwistic names and Judean naming practices in Babylonia, see Zadok 2002; Pearce and Wunsch 2014, 14-93; Pearce 2015, 7-32. 
thermore, because travelling and the transportation of goods are an integral part of commercial activity, Judean merchants provide an example of people who could have maintained connections between the communities in Judah and Babylonia. The article begins with an overview of Babylonian trade and traders in the first millennium BCE. This is followed by a case study of the descendants of Arih, a family of Judean royal merchants in Sippar. In order to situate them in the right socioeconomic context, I study the community of traders in Sippar more generally and explore the evidence of other Judean merchants in Babylonia. Finally, I discuss the role of Judean merchants in longdistance trade.

\section{Trade and Traders in Babylonia}

Trade in first-millennium Babylonia was not a state-monopolised business, and a diverse group of people engaged in mercantile activities. ${ }^{10}$ On the one hand, some people were explicitly identified as tamkāru ('ídam.gàr), "merchant", or

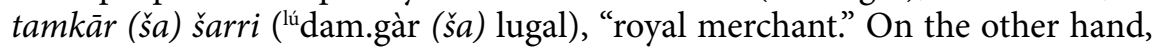
urban families played a central role in local trade in agricultural staples and some even engaged in long-distance trade, although these people are never called tamkäru or tamkār šarri in the documents. ${ }^{11}$

The title tamkāru is attested in cuneiform documentation from the Old Akkadian period onwards, ${ }^{12}$ and the term was used both in the Neo-Assyrian and Neo-Babylonian periods. In the first millennium, tamkāru probably denoted the specific status of a professional merchant, but it is unclear if tam$k \bar{a} r u s$ were exclusively royal officials. The close connection between tamkārus and the royal administration is evident in the Neo-Assyrian period, and quite many tamkārus worked for the king and his high officials. ${ }^{13}$ However, Laetitia Graslin-Thomé argues that this view is skewed by the nature of the available evidence and that not all tamkärus worked for the state as some of them could have been independent actors. ${ }^{14}$

In the Neo-Babylonian period, some tamkārus bore titles describing the type of trade they were specialised in, ${ }^{15}$ and some played a role in long-distance trade. ${ }^{16}$ Many luxury products - such as gold, incense, and dyes - were of foreign origin and could be obtained only via extensive trade networks cov-

10 On trade and merchants in first-millennium Babylonia, see Oppenheim 1967; Dandamayev 1995, 523-30; Joannès 1999, 175-94; Heltzer 2006, 347-51; Graslin-Thomé 2009; GraslinThomé 2014, 603-28; Jursa 2010, 214-28.

11 Dandamayev 1995; Jursa 2004a, 130-31; Jursa 2010, 224-25.

12 CAD T, 125.

13 Elat 1987, 233-54; Radner 1999, 101-26.

14 Graslin-Thomé 2009, 384-90.

15 Sheep and date merchants are explicitly mentioned in the archives. See Joannès, 1999, 179.

16 Dandamayev 1995, 527; Joannès 1999, 177-78. 
ering the whole Near East. ${ }^{17}$ Tamkārus were also involved in the temple economy: they bought staples from the temple and acquired luxury products for that institution. ${ }^{18}$ In addition to tamkārus, royal merchants, tamkār (̌̌a) šarris, are attested in Babylonian sources. Even though it is clear that royal merchants were somehow affiliated with the palace, there is not enough evidence to determine whether or not they were royal officials. ${ }^{19}$ Furthermore, the terminological difference between tamkāru and tamkär šarri is not clear and the terms might have been interchangeable. ${ }^{20}$

However, it is important to note that tamkārus did not monopolise Babylonian domestic or long-distance trade, and people never identified as tam$k \bar{a} r u s$ engaged in various trading activities. Prosperous entrepreneurial families, such as the Egibis of Babylon and the Murašûs of Nippur, played a central role in the transportation of staples from the countryside to cities and their retail sale to urban customers. Entrepreneurs ${ }^{21}$ bought crops from farmers, thus providing them with a channel to sell their products and a means to pay taxes. ${ }^{22}$ Long-distance trade was only a minor interest for these wealthy families. ${ }^{23}$ Nevertheless, some Babylonian businessmen - such as Iššar-tarỉbi, son of Bunene-ibni - actively participated in long-distance trade, even though they are not referred to as tamkārus. ${ }^{24}$

The existence of people like Ǐšar-taribi, who earned their living from trade but did not bear the title of tamkāru, illustrates the complex meanings of the designations discussed above. Tamkāru was not a blanket term referring to anybody involved in domestic or long-distance trade, but rather denoted a certain status or affiliation. As it appears that the tamkāru of the Neo-Assyrian period and tamkār šarri of the Neo-Babylonian period were closely connected with the royal administration, it is possible that an institutional connection underlay the Neo-Babylonian term tamkāru as well. This does not necessarily mean that tamkärus were dependent on the palace or temple; such an institution could be seen more as a client or, alternatively, an employer. Be this as it may,

17 Oppenheim 1967; Joannès 1999, 184-89; Graslin-Thomé 2009, 179-338.

18 Joannès 1999, 177-78; Jursa 2010, 580-81.

19 See Dandamayev 1995; Joannès 1999, 178; Jursa 2004a, 129-30; Heltzer 2006; Graslin-Thomé 2009, 397-98, 400-402.

20 Jursa 2004a, 130; Jursa 2010, 580. However, Dandamayev 1995; Joannès 1999, 177-79; and Graslin-Thomé, 2009, 401-2, take tamkāru and tamkār šarri as two different categories.

21 In this study, a distinction is made between the priestly and entrepreneurial (or mercantile) circles of Babylonian society, following Jursa 2010, 282-94; and Waerzeggers 2014a, 119-24. "Priestly" refers here to the people who held prebends at Babylonian temples and whose income derived from these prebends and inherited landholdings. "Entrepreneurial" refers to the people who actively participated in business activities and whose income did not primarily derive from prebends or inherited property. "Mercantile" specifically refers to those entrepreneurs whose business was characterised by trade.

22 Stolper 1985, 27-28; Wunsch 1993, 19-55; Wunsch 2007, 238-39; Jursa 2010, 214-20.

23 Jursa 2004a, 130-31; pace Dandamayev 1995, 528.

24 On the available evidence of long-distance trade in private archives, see Jursa 2010, 224-25. On Iššar-tarībi, see below. 
it is safe to conclude that both tamkārus and tamkār šarris were professional merchants in the Neo-Babylonian period, the latter group being employed by the state in one way or another. ${ }^{25}$

Many merchants who engaged in long-distance trade were evidently of foreign origin, as A. Leo Oppenheim suggested already in $1967 .{ }^{26}$ Several royal merchants from the sixth century indeed bear non-Babylonian names, ${ }^{27}$ and in Nebuchadnezzar's Hofkalender the official in charge of royal merchants ( $r a b$ tamkāri ša šarri) bears the West Semitic name Hanūnu. ${ }^{28}$ The exact duties of this official are unknown, but his title and appearance among other royal officials in the Hofkalender emphasises the close connection between tamkār šarris and the royal administration. There are no other certain attestations of $r a b$ tamkārī ša šarri in Neo-Assyrian or Neo-Babylonian documents. In contrast, persons identified as rab tamkārī, "the chief of merchants", appear in NeoAssyrian and Neo-Babylonian texts. ${ }^{29}$ It is plausible that they worked for an institution and were responsible for the management of their employer's traders or trading operations. ${ }^{30}$

\section{Judean Royal Merchants in Sippar}

\subsection{Sources}

Six cuneiform tablets pertain to the descendants of Arih, a family of Judean royal merchants in Sippar. In 1989, Martha T. Roth published a marriage agreement (BM 65149) between the Judean bride Kaššāya/Amušê and the Babylonian groom Guzānu/Kiribtu/Ararru ${ }^{31}$ from the fifth year of Cyrus. ${ }^{32}$ Another

25 See Jursa $2010,580$.

26 Oppenheim 1967, 253-54. He is followed by Jursa 2004a, 131. On the situation in the NeoAssyrian period, see Nissinen 2014, $288+$ n. 101.

27 See Zadok 2004, 112-13; Heltzer 2006; Bloch 2014. Add also text no. 17 from the Neirabian archive (Dhorme 1928, 63; see Tolini 2015, $84+$ n. 83).

28 Da Riva 2013, col. vi*:18'. On the name, see Zadok 2004, 114.

29 ND 2684: 9 (Kalhu, the reign of Sargon II?, edited in Parker 1961, 43); possibly SAA 79 obv. col. ii:20' (Nineveh, the reign of Esarhaddon or Assurbanipal); CT 55 823: 2 (Sippar, 21-V-13 Nbn); Camb 384:11 (Humaděšu?, 1-IX-7 Camb; for this and the following text, see Zadok 1976, 67-74); Pinches 1892, 134:9 (Humadēšu?, 17-X-7 [Camb]); Cameron 1948, no. 85:3 (Babylonia?, 25-IX-20 Dar); MacGinnis 1995, no. 118:6 (Sippar, 5-I-Dar). Nbn 464:6 (Sippar, 13-X-10 Nbn) reads lígal lúdam.meš [...], but Bongenaar 1997, 138-39, 406, completes the text as lígal lídam.<gàr >.meš [šá lugal]. Muhammad A. Dandamayev $(1971,74)$ and Michael Heltzer $(2006,348)$ understand the text similarly, but cf. MacGinnis 1994, 205 + n. 38 .

30 See Elat 1987, 253-54; Bongenaar 1997, 138; Radner 1999, 101 n. 3.

31 In Babylonian documents, a person's filiation is given as "PN1, son of PN2" or "PN1, son of $\mathrm{PN} 2$, descendant of PN3", the latter in the case when the person belonged to the urban elite with family names. The standard Assyriological convention is to abbreviate these sequences as $\mathrm{PN} 1 / \mathrm{PN} 2$ or $\mathrm{PN} 1 / \mathrm{PN} 2 / \mathrm{PN} 3$, respectively.

32 Roth 1989, no. 26 (= BMA 26). 
version of the marriage agreement (BM 68921), not a duplicate, was discussed by Roth in 1989 but published in full by Michael Jursa only in $2001 .^{33}$ In 2007, Jursa identified an additional three tablets relating to the bride's family. ${ }^{34}$ The present author collated these three tablets (BM 68420,74411, and 75434) in the British Museum in July 2014. Yigal Bloch added yet another tablet (CT 4 21a) to the group in his article in $2014 . .^{35}$ Bloch's article presents an edition of all the six tablets and a discussion of their contents and relevance for the study of Judeans in Babylonia. Because of their recent publication, there is no need to edit any texts here, but some emendations to Bloch's readings are suggested. The numbering of the tablets follows Bloch 2014.

The earliest text of the group is no. 3, written in Sippar in the tenth year of Nabonidus (BM 75434, 18-II-10 Nbn, 546 BCE). It is a promissory note for half a mina of silver, owed by the royal merchant (tamkār šarri) Basia, son of Arih, to Marduka/Bēl-ïpuš/Mušèzib. Unlike his creditor, Basia is not known from other sources, and he was not a member of the urban Babylonian social stratum bearing family names. ${ }^{36}$ Judging by his patronymic, he was instead of foreign origin. ${ }^{37}$ His creditor Marduka was a well-known tithe farmer ( $\check{s} a$ muhhi ěsrî) of the Ebabbar temple in Sippar. ${ }^{38}$ Because it is unlikely that the royal merchant Basia owed tithes to Marduka, the transaction was perhaps connected to the resale of agricultural produce. It is noteworthy that the tablet was written at the time of the barley harvest and repayment was to take place a month later. Professional merchants customarily bought dates from the Ebabbar temple, ${ }^{39}$ and a purchase of barley might have been behind this promissory note.

Two more tablets pertaining to the descendants of Arih were written in the eleventh and twelfth years of Nabonidus. They are similar in their contents, both referring to house rental payments and trade in gold. The more complete tablet of the two is no. 5 (BM 74411, 30-II-12 Nbn, $544 \mathrm{BCE}$ ), a receipt of sale which originates from the Ebabbar temple, even though the temple or the place of writing is not explicitly mentioned. ${ }^{40}$ The transaction did not take place between

33 Jursa 2001.

34 Jursa 2007.

35 Bloch 2014

36 The use of family names (i.e. three-tier genealogies) is a feature that distinguishes a number of Babylonian families from the rest of the population and generally suggests their elevated social standing. See Nielsen 2011.

37 The meaning and etymology of Arih is not clear. See Zadok 2004, 108-110; Bloch 2014, 128 29; Radner and Baker 1998-2011, 131. Add OIP 122 15, a sale of slaves written in Biranatu in 24 Nbk (580 BCE), to Zadok's list of people named Arih in Babylonia (see Jursa 2006, 45354; Jursa 2007, n. 4). In this text, a certain Šadiku/Arih is the buyer of the slaves. Jursa 2006, 453, suggests a possible connection between this text and the text group from Sippar, but this remains hypothetical due to the lack of any other evidence than the occurrence of the name Arih.

38 Bongenaar 1997, 429-33; Jursa 1998, esp. 49-52.

39 Jursa $2010,580-84$.

40 See Bloch 2014, 147 n. 64, 158. 
two individuals; only the name of the seller of gold, Amušê/Arih, is referred to. The purchaser remains anonymous, and neither the scribe nor the witnesses of the document are mentioned. However, the origin of the capital required for the purchase is specified in detail. The silver component was partially taken from a storehouse, part of it originated as house rental payments, and a substantial part of the price was paid in 100 kor of dates, the equivalent of 3 minas of silver. The value of the transaction was not negligible: Amušê sold 42 shekels of gold for 5 minas and 36 shekels of silver. ${ }^{41}$ These features point towards an institutional background of the transaction, in this case the Ebabbar temple.

Text no. 4 (BM 68420, III-11 Nbn, $545 \mathrm{BCE}$ ) is broken, but comparison with no. 5 helps to understand its contents. It was written in Sippar and originated in the Ebabbar administration, as the property of Šamaš is referred to on line 4. The structure of the text follows no. 5: information on house rental payments is combined with a reference to gold received from Marduka, son of Arih. A certain Marduka is also attested on line 1, but he seems to be one of the suppliers of silver and not identical with Marduka/Arih. Judging by the similarities between texts 4 and 5 , it is reasonable to suggest that no. 4 pertains to a sale of gold to Ebabbar by Marduka, son of Arih. Two points are of interest here. First, gold was a rare metal in ancient Babylonia, used solely for luxurious or cultic purposes, and silver was used as the medium of exchange. ${ }^{42}$ Second, trade in gold was the business of professional merchants ${ }^{43}$ which strongly supports the conclusion that both Amušê and Marduka were tamkārus, if not royal merchants (tamkār šarri).

A number of comments on and corrections to Bloch's edition of the texts are in order here. According to Bloch, the operative section of text no. 4 continues from the obverse to the reverse and there is no witness list before the name of the scribe. ${ }^{44}$ Only the last two or three signs of the first four lines of the reverse are visible, and according to my collation of the tablet at the British Museum, they most likely present the remnants of a witness list. The beginning of the reverse can be reconstructed as follows:

41 Line 10 concerning the amount of silver is broken, which leaves some room for different interpretations. The first readable sign must be either $1 / 2$ or $5 / 6$, followed by ma.na 6 gín kù.babbar. The amount of silver is thus $\mathrm{x}$ minas and 36 or 56 shekels. Line 11 reads $[a-n] a 5 / 6$ ma.na 2 gín kù.gi ki-i pi-i 8.kam. Accordingly, gold was exchanged for silver at a ratio of 1 to 8 . Based on the information on line 11, Jursa $(2010,524 \mathrm{n}$. 2856) multiplies 52 shekels of gold by 8 , which makes 6 minas and 56 shekels of silver. However, as it appears that the origin of the silver is described on the preceding lines, Bloch $(2014,156-58)$ arrives at a different conclusion. If the broken numeral at the beginning of line 7 is 1 , the sum of the payments is 5 minas and 36 shekels of silver. Because the cuneiform signs for $2 / 3$ and $5 / 6$ closely resemble each other, Bloch suggests that $5 / 6$ minas should be taken as a scribal error for $2 / 3$ minas on line 11 . This fits the ratio of 1 to 8 ( 42 shekels of gold for 5 minas and 36 shekels of silver). Considering the transaction as a whole, Bloch's suggestion is to be followed.

42 Jursa 2010, $474+$ n. 2584, 508, 524 .

43 Jursa 2007.

44 Bloch 2014, 154-56. 
8) [lúmu-gin PN1 a]-šú šá

9) [PN2 a lúsanga-s] ip-parki

10) [PN3 a-šú šá $\left.{ }^{\mathrm{I}}\right]$ su- ${ }^{\mathrm{d}}$ amar.utu ${ }^{45}$

11) [a ${ }^{\text {lúsanga- dinanna-tin.t] } \mathrm{ir}^{\mathrm{ki}}{ }^{\mathrm{i}} 6 \mathrm{a}}$

12) ["úumbisag Idag?]-mu-si.sá a-šú šá

13) [ $[\mathrm{x}$ ? $]-b a ?-[\mathrm{x}]$ a lúsanga- ${ }^{\mathrm{d}}$ inanna-tin.tir ${ }^{\mathrm{ki}}$

[Witnesses: PN1, son] of [PN2, descendant of Šangû-S]ippar; [PN3, son of] Erība-Marduk, [descendant of Šangû-Ištar-Bāb]ili. [Scribe: Nabû?]-šum-līšir, son of [Balassu?], descendant of Šangû-Ištar-Bābili.

Two sequences of names with three-tier genealogies fit the available space and the remnants of the signs perfectly. Moreover, the families of Šangû-Sippar (Šangû-Šamaš) and Šangû-Ištar-Bābili played a central role among the priesthood of Ebabbar and they are frequently attested in the documentation from the temple archive. ${ }^{47}$ The person mentioned on lines $10-11$ was probably one of the sons of Erība-Marduk/Marduk-zēr-ibni/Šangû-Ištar-Bābili. ${ }^{48}$ As Bloch's copy of the tablet shows, the last three signs of the personal name on line 12 are at least partially visible. The remnants of the sign before "si.sá" suggest reading "mu", resulting in a personal name ending with "šum-lǐšir." From the ŠangûIštar-Bābili family, only one such man, Nabû-šum-līšir/Balassu, is known to me, but reconstructing his patronymic on line 13 causes difficulties. ${ }^{49}$

On line 2 in text no. 5, one should read "1 me gur zú.[lum.ma]" ("100 kor of da[tes]"), instead of "1 me gur ina gišr bán" (“100 kor by the sūtu measure"). ${ }^{50} \mathrm{~A}$ reference to the type of produce makes the most sense in this context, and the price of 1.8 shekels of silver per 1 kor of dates fits well with the range of date prices at Ebabbar in the twelfth year of Nabonidus. ${ }^{51}$ Jursa has convincingly shown that Ebabbar could not set the cost of dates independently, but market mechanisms determined the prices. ${ }^{52}$ Because the price paid for gold is also not exceptional, Bloch's conclusion that Ebabbar was "able to bend the prices in its favour" appears to be mistaken. ${ }^{53}$ The last two signs on line 2 should perhaps be read as é gur ${ }_{7}$,

45 According to Bloch 2014, 155, "[t]he signs at the end of 1.10 are slightly deformed." However, instead of "máš-šu" (ibid., 154), the signs quite clearly present the sequence "damar.utu."

46 The reading “ $\mathrm{t}] \mathrm{ir}^{\mathrm{k} \mathrm{k} \text { ” }}$ fits the preserved signs better than Bloch's (p. 154) reading “ $\left.e\right\urcorner-e h$ !."

47 Zawadzki 1990, 17-25; Bongenaar 1997, 12-15, 435-63; Waerzeggers 2014a, 28-29.

48 Bongenaar 1997, 436 with further references.

49 One sign of the patronymic is visible on line 13. Bloch reads it as "i", but I only see three horizontal wedges. The sign might thus be "ba", but there is not enough space to insert "lat-su" in the break after the sign. On Nabû-šum-līšir/Balassu/Šangû-Ištar-Bābili, see Bongenaar 1997, 439-40.

50 Cf. Jursa 2010, 534.

51 Jursa 2010, 593.

52 Jursa 2010, 590-91.

53 Bloch 2014,131 . On the prices which the Eanna temple of Uruk paid for gold, see Joannès $1982,242-44$. 
"storehouse." Moreover, $1 \frac{1}{3}$ gín on line 6 is not a mistake, but a common way of referring to $1 / 3$ mina in Neo-Babylonian economic texts. ${ }^{54}$ In texts 4 and 5, Bloch systematically translates ina qāt (ina šu" ) as "under the charge of", referring to a commodity at the disposal of someone. However, ina qät should often be translated simply as "from", pointing to the payer or supplier of the goods in question. ${ }^{55}$ This seems to be the correct translation, at least in no. 5 where part of the dates and silver for the purchase are supplied by Kīnā and Bakûa.

Basia and Marduka both had Babylonian names ${ }^{56}$ but Amušès name points to his non-Babylonian origin. A-mu-še-e is the Babylonian spelling of $H w \check{s}$, Hosea or Hoshea, a name attested several times in the Hebrew Bible. ${ }^{57}$ The significant differences in the spelling result from the characteristics of Babylonian in which the West Semitic $h$ could not be accurately presented and $w$ was customarily written as $m$ or left completely out. ${ }^{58}$ According to Zadok, Hosea "is an exclusively Hebrew name." ${ }^{59}$ This statement finds support in the few attestations of the name in Neo-Babylonian sources: only three different individuals used the name, and two of them had blood relatives with Yahwistic names. ${ }^{60}$ Moreover, a longer theophoric form of this name, Amuš-Yāma, is attested in three documents from the surroundings of Yāhūdu. ${ }^{61}$

Arih is a rare foreign name in Babylonian sources. It is thus striking that three sons of Arih are attested in the economic sphere of the Ebabbar temple within a period of three years. Furthermore, Basia is explicitly called a royal merchant, whereas Amušê and Marduka also appear in a context related to trade. This evidence alone might not be strong enough to confirm that the three men were brothers, but two marriage agreements corroborate their family relationship and Judean background. Bēl-uballiṭ (son of Amušê), his unnamed brother, and their mother Gudadaditu gave their sister and daughter Kaššāya in marriage in the fifth year of Cyrus (no. 2, BM 68921, II-[5 Cyr], 534 BCE). ${ }^{62}$ The groom was Guzānu, son of Kiribtu, whose family name of Ararru betrays his Babylonian descent. For an unknown reason, the marriage agreement of Kaššāya and Guzānu was drafted again a month later (no. 1, BM 65149, 11-III-5

54 Lorenz 2005/2006, 248-51.

55 CAD E, 404; CAD Q, 192.

56 Even though the etymology of both names is disputed, they are typical of the Neo-Babylonian onomasticon. See PNA 1/II, 276; PNA 2/II, 704; Streck 2011, 116; Bloch 2014, 129, 153; Pearce and Wunsch 2014, 44, 65; Nielsen 2015, 58-59, 206, 208-9.

57 Zadok 1979, 26-27; Jursa 2007; Bloch 2014, 145-46. An alternative spelling of the name in Babylonian was Ú-še-eh (PBS 2/1 60), for which see Stolper 1976, 26 n. 10; Zadok 1979, 26. For some attestations of the name in the Hebrew Bible, see 2 Kings 17-18; Hosea 1. See also the Neo-Assyrian attestations of this name in PNA 1/I, 238; PNA 3/II, 1421.

58 Soden 1969, $§ 8,21,23,25,31$. See also Coogan 1973, 189-90; and Bloch 2014, 122.

59 Zadok 1979, 26.

60 Amušê (Nbn 1); Amušê/Arih (no. 5; as a patronymic in nos. 1, 2, and 6); Matan-Yāma/Amušê (Stolper, 1985, no. 113; written as Ú -še-eh in PBS 2/1 60).

61 BaAr 6 3; CUSAS 28 34, 45. See Pearce and Wunsch 2014, 39.

62 The text has been previously edited in Jursa 2001, See also Roth 1989, 94-95. 
Cyr). ${ }^{63}$ The witnesses had changed somewhat, but the contract remained almost the same. The only major difference seems to be the absence of the unidentified brother, who, together with his brother and mother, gave Kaššāya in marriage in no. 2. Two brothers of the bride, Šamaš-iddin and Nabû-ittannu, and a brother of the groom, Lâbâši, are among the witnesses of both documents. Amušê, the father of the bride, was absent on both occasions.

The patronymic of Amušê is not mentioned in the marriage agreements, but some of the numerous witnesses establish a link between the bride's family and the three sons of Arih discussed above. Both marriage agreements were witnessed by four royal merchants, Ahu-Yāma/Arih, Arad-Gula/Šamri-Yāma, Niqūdu/Mušallammu, and Šamaš-aplu-ușur/Rapê. As in the previous three documents, people engaged in professional trade play a major role here. Moreover, they all have a West Semitic name or patronymic, two of which are Yahwistic. ${ }^{64}$ The key person here is the first witness, Ahu-Yāma/Arih, who must have been a brother of Basia, Marduka, and Amušê. Arih is a rarely attested non-Babylonian name, but it appears four times as a patronymic of professional merchants in Sippar within a period of 12 years. This leaves little room for doubt. Accordingly, Kaššāya's father must be the same person as Amušê/ Arih in text no. 5. The Yahwistic name of Ahu-Yāma and the distinctly Judean name Amušê confirm the immigrant background of this family, which appears to consist of Judean royal merchants living in Sippar. ${ }^{65}$

The three documents pertaining to Basia, Marduka, and Amušê originated in the administration of the Ebabbar temple and may thus belong to the temple archive. Alternatively, they were handed over to the merchants after the transactions were completed and the debts were paid back. ${ }^{66}$ The marriage agreements between Kaššãya and Guzānu are not related to the temple, and, together with the three other documents, they may be the remnants of the private archive of the descendants of Arih. The documents belong to the 82-9-18, AH 82-9$18 \mathrm{~A}$, and AH 83-1-18 collections of the British Museum, which predominantly constitute of Ebabbar texts but also contain documents from private archives. ${ }^{67}$ It is likely that the private archives were unearthed together with the temple archive.$^{68}$ Most of the private archives found in the vicinity of Ebabbar relate to people who held prebends and might have kept their private documents on the

63 The text has been previously edited as BMA 26. See also Jursa 2001; Jursa 2004b, 90-91. Bloch $(2014,132)$ suggests that the contract was drafted again because "some difficulties arose with the marriage of Kaššaya."

64 On Mušallammu, see Abraham 2005/2006, 216; and on Rapê, PNA 3/1, 1032-33. On both names, see Bloch 2014, 133.

65 For the family tree of the descendants of Arih, see Bloch 2014, 127.

66 Promissory notes were usually handed over to the debtor when the debt was paid back; however, this was not always the case. See Jursa 2005, 42.

67 Leichty and Grayson 1987, 143, 233, 247; Leichty et al. 1988, 4, 34 (notice that BM 75434 is catalogued as a receipt for a sheep); Waerzeggers 2014a, 145.

68 Waerzeggers 2014, $16+$ n. 6 . 
temple premises. ${ }^{69}$ At the same time, some private archives - such as the archive of the non-prebendary trader Iššar-taribi - were deposited in the vicinity of the Ebabbar material because of their connection to the archive of Marduk-rēmanni. $^{70}$ The main protagonist of this archive, Marduk-rēmanni, was an influential man both in the temple and the trading communities of Sippar. The parties of the present marriage agreements belonged to the Sipparean trading community and knew people in Marduk-rēmanni's circles, ${ }^{71}$ but nothing suggests that a connection to the archive of Marduk-rēmanni brought these texts in contact with the Ebabbar archive. However, the discovery of other - also non-prebendary - private archives at Ebabbar confirms that the documents pertaining to the descendants of Arih do not necessarily belong to the temple archive but they may constitute the remnants of the private archive of the Judean family.

Even though the bride's family was of Judean origin, the marriage agreements comply with the standard features of such documents from sixth-century Babylonia. ${ }^{72}$ As customary, the dowry given by the bride's family is described in detail: it included jewellery worth 20 shekels of silver, ${ }^{73}$ earrings worth one shekel of gold, an Akkadian bed, five chairs, a table, a goblet, and a bronze platter. Kaššāya's family could afford to provide their daughter with some dowry, but it is noteworthy that no silver, slaves, or real estate was included. These items normally constituted the most valuable part of the dowry and were of primary interest for the husband's family, whereas jewellery, furniture, and household utensils were intended for the personal use of the bride and for housekeeping. ${ }^{74}$

The small size of the dowry may lead to two different conclusions: either Kaššàya's family could not afford to give anything else or they did not need to. The stipulations about divorce and adultery may indicate that the families of Kaššāya and Guzānu were not very wealthy. In the case of divorce, Guzānu was to pay six minas of silver and let his wife return to her paternal house. ${ }^{75}$ If Kaššàya was found with another man, she would die by the iron dagger. ${ }^{76}$ The iron dagger clause is attested in marriage agreements with a small dowry or none at all, but which include a stipulation about a payment from the husband to his wife in the case of divorce. According to Cornelia Wunsch, this implies that economic factors dictated the choice to include these stipulations in the

69 Bongenaar 2000, esp. 91-92. See also Jursa 2005, 120-29; Waerzeggers 2014a, 15-22, 144-46.

70 Waerzeggers 2014a, esp. 19-22, 86-89.

71 See below.

72 See Roth 1989; Abraham 2015, 45.

$731 / 3$ gín šu-kut'-tut ${ }^{4}$. As in no. $5,1 / 3$ gín refers here most likely to $1 / 3$ mina (i. e. 20 shekels of silver). Wunsch 2003, 4 n. 14; Jursa 2004b, 91.

74 Roth 1989/1990, esp. 1.

75 On divorce in Babylonian marriage agreements, see Roth 1989, 12-15; Oelsner et al. 2003, 935-36.

76 On the iron dagger clause, see Roth 1988, 186-206; Wunsch 2003, 3-7; Waerzeggers 2016. 
marriage agreement. ${ }^{77}$ If the bride's family could afford to give a substantial dowry, the economic consequences of losing the dowry in the case of divorce were serious. Accordingly, no stipulations about compensatory payment were necessary. The adultery of the wife must have been severely punished in these marriages as well, even though this is not made explicit in the agreements. In the marriage agreements of less wealthy people, the clauses about huge compensatory payment and death by the iron dagger emphasised the serious consequences of divorce and adultery.

Caroline Waerzeggers understands the social context of the iron dagger clause differently, and her interpretation fits in better with the available evidence. ${ }^{78}$ She notes that the connection between poverty and the iron dagger clause is not consistent and that the clause was also used in some marriage agreements involving dowry. At the same time, the clause is never found in marriage agreements between parties who bore family names, but it is always attested in marriage agreements between parties who did not bear family names. In marriage agreements between parties from different social backgrounds, the status of the bride was decisive. If she bore a family name, the iron dagger clause was not included. It thus appears that the usage of the iron dagger clause was related to the social background of the parties involved, not primarily to their wealth. In the case of Kaššāya and Guzānu, the non-Babylonian background of the bride, not her poverty, prompted the inclusion of the iron dagger clause in the marriage agreements.

Moreover, it was not only property that was transferred in marriage, but the families of the husband and bride also shared each other's prestige and social networks. That is why the wealthy Egibis, for instance, were able to give their daughters in marriage with relatively small dowries. Becoming a member of the family was already profitable in a socioeconomic sense. ${ }^{79}$ Kaššàya's small dowry indicates that her husband's family placed a high value on marriage ties to a family of royal merchants and that they were satisfied with a dowry consisting only of jewellery and household goods. A daughter of royal merchants was a highly prized bride, even if her family was of foreign origin. Accordingly, Kaššāya’s small dowry is hardly indicative of the modest wealth of her family.

Before addressing the social status and networks of the descendants of Arih in more detail, two more documents have to be discussed. Text no. 6 (CT 4 21a, 5-I-19 Dar, 503 BCE) was drafted in Sippar 31 years after the marriage agreements. The document is a lease of 30 hasbattu vessels, which were probably used in a beer-brewing and tavern-keeping business by the lessee Šamašuballiț/Nādin/Bā’iru. ${ }^{80}$ The lessor was someone called Rīmūt/Šamaš-zēr-ibni,

77 Wunsch 2003, 3-7.

78 Waerzeggers 2016.

79 Roth 1991, 19-37.

80 On the connection between hașbattu vessels, beer, and taverns, see Joannès 1992; and Tolini 2013. 
and the third witness was a certain Bèl-iddin/Amušê. The document belongs to the private archive of Bēl-ittannu/Šamaš-uballiț/Ša-nāšišu.$^{81}$ As will be shown below, prosopographical evidence connects this document closely to the marriage agreements, and Bēl-iddin must have been a brother of Kaššãya.

A second document (Nbn 1) belongs to the Ebabbar archive and was written in the accession year of Nabonidus (18-III-0 Nbn, $556 \mathrm{BCE}$ ). It is a partially broken list of people, kur.ra garments, and small amounts of silver. The garments were most likely distributed to the workers of the temple, and the value of each garment in silver is given on the list. ${ }^{82}$ The recipients are listed without their patronymics, and a certain Amušê is mentioned on line 13. Even though he was a contemporary of the sons of Arih and attested in Sippar, he appears to be a member of the temple personnel and thus different from the (royal) merchant Amušê. In any case, he was probably of Judean origin, given the rarity of the name and its connection with Yahwistic names in Babylonian sources.

\subsection{Social Network}

To have a better understanding of Kaššāya and her family of royal merchants, it is necessary to study the other people who appear in the documents discussed above. ${ }^{83}$ The extensive research done on Sipparean cuneiform documentation over the past 25 years allows me to locate the descendants of Arih and their acquaintances in a wider social context. ${ }^{84}$ However, before mapping out the social networks, it is helpful to focus briefly on the city of Sippar in the sixth century BCE.

The city of Sippar on the banks of the Euphrates was ideally located for trading purposes. The courses of the Euphrates and the Tigris were closest to one another near Sippar, and the trading routes to the Iranian plateau beyond the Tigris and to the Levant beyond the Euphrates met naturally in Sippar. In addition, the state strongly invested in the Sippar region in the sixth century BCE, and royal projects created a boom in agriculture and trade. ${ }^{85}$ Consequently, a vibrant community of local businessmen, foreign traders, and royal merchants emerged around the harbour of Sippar. On the other hand, Sippar was an important cult centre of the sun god Şamaš, whose temple Ebabbar stood in the middle of the city. The priests of Ebabbar formed their own closed com-

81 The Ša-nāšišu B archive in Jursa 2005, 126-27.

82 On kur.ra garments and their distribution to temple personnel, see Bongenaar 1997, 39-40; Zawadzki 2010, esp. 412-14.

83 Some aspects of this social network are studied in Waerzeggers 2014b, 140.

84 The most important studies for the present discussion are Bongenaar 1997; and Waerzeggers 2014a. See the latter for further literature on Sippar.

85 Woods 2005, 37-40; Jursa and Baker 2011, 533-37; Jursa 2010, 64, 84-86, 322-59; Waerzeggers 2014a, $2-4$. 
munity, and they rarely took part in trading activities as private persons, even though the temple itself traded regularly with outsiders. The communities of priests and traders can thus be seen as two distinct groups in Sipparean society. ${ }^{86}$ The international character of the Sipparean trading community is also reflected in the marriage agreements of Kaššàya and Guzānu. In addition to Amušề's brother Ahu-Yāma, three other royal merchants witnessed the marriage agreements, and they all bore West Semitic patronymics. This corroborates the well-established view that people of foreign origin played a key role in professional trade in Babylonia.

The descendants of Arih knew people from both the temple and the trading communities of Sippar. In their business transactions with the Ebabbar temple, Basia, Marduka, and Amušê came into contact with a well-known tithe farmer of the temple and with members of the most important priestly families in Sippar. ${ }^{87}$ These transactions are important in showing that merchants of Judean origin customarily traded with the temple and met people working for the institution and belonging to priestly families. However, these encounters were professional in nature, and they tell nothing about the friendship or family ties of the Judean family. When it comes to their private circles, it is more fruitful to study the people attested in the marriage agreements.

An evident point of departure for this discussion is the family of Kaššãya's husband Guzānu/Kiribtu/Ararru. The family name Ararru, "miller", is very rare in the Neo-Babylonian sources, and only seven certain attestations of the name are known to me. ${ }^{88}$ Two of these documents - namely the present marriage agreements - come from Sippar, four from Babylon, and one probably from Babylon or Sippar. The earliest document from Babylon records the sale of an unbuilt plot in the city from the sixth year of Esarhaddon (20V-6 Esarh, $675 \mathrm{BCE})$. The seller was Bēl-ēreš//Ararru and the buyer a certain Ea-qayal-išemme. ${ }^{89}$ The tablet was unearthed in the Ninurta temple in Babylon, where the Sîn-ili archive was found. ${ }^{90}$ As the tablet is older than the archive, they may be unrelated. It is also possible that the tablet was kept in the archive to record the ownership history of the plot which was later bought by the Sîn-ilì family. ${ }^{91}$

86 On the priests of Ebabbar, see Bongenaar 1997. Sipparean society is studied in Waerzeggers 2014a, 119-26.

87 See above.

88 I am grateful to Cornelia Wunsch for her substantial help in gathering the evidence. See also Tallqvist 1905, 67; CAD A/2, 233; Wunsch 2014, 303; Nielsen 2015, 36. There are three other documents that might mention the family name Ararru: Dar 411:13 (but according to Abraham 2004, no. 119, the sign should be read as šitim, "Itinnu"); OECT 10 295; Thureau-Dangin 1922, 85:14 (=RINAP 4 126).

89 Jakob-Rost 1970, no. 4. Note that according to Jakob-Rost's translation of the broken passage, the seller was Ea-qayal-išemme and the buyer Bēl-ēreš. See Pedersén 2005a, 239.

90 Pedersén 2005b, 228-32, 239. On the Sîn-ilī archive, see Jursa 2005, 69-71.

91 Pedersén 2005b, 228-31. 
Two tablets from Babylon belong to the Egibi archive, the first one being a promissory note that concerns a house rental payment (Nbk 137, 21-IV-23 Nbk, 582 BCE). Bēl-iddin/Balassu/Ararru is listed as the second witness. The other document from the Egibi archive is also a promissory note (Nbn 600, 5-III-12 Nbn, $544 \mathrm{BCE}$ ), which records a debt of 23 kor (4140 litres) of dates to be paid back with 25 vats of good beer. The creditor was Itti-Marduk-balāțu/Nabû-ahhē-iddin/Egibi and the debtor Balātu/Marduk-nāșir/Ararru.

The fourth tablet from Babylon is a promissory for 6 kor of dates (VAS 3 53, 4-III-11 Nbn, 545 BCE), written by a scribe called Arad-Marduk/Bēl-[...]/ Ararru. The names of the creditor and debtor are both peculiar, the former being Nabû-ahhē-bulliț/Aššur-mutaqqin-dīn(?) and the latter Mil-ki-šu-mulugal-ùru/Ha-am-[ma?]-ta-a-a. Names containing the theophoric element Aššur are rare in Babylonia, ${ }^{92}$ and $m l k$ is not an Akkadian but a common West Semitic root. ${ }^{93}$ If Hammatayya is the correct restoration, the patronymic means "the Hamathean." ${ }^{4}$ The tablet cannot be assigned to any known archive. Yet another text concerning the Ararru family most likely originates from Babylon or, alternatively, from Sippar. The unpublished tablet BM 77945 (19 Nbk?, 586 BCE?) mentions PN/Aplā/Ararru among the witnesses of a lawsuit. ${ }^{95}$

There is no prosopographical evidence to demonstrate that the descendants of Ararru were all members of a single family. However, several interesting conclusions can be drawn from the seven texts discussed above. First of all, nothing suggests that the Ararrus held prebends at Ebabbar or any other temple in Babylonia. Even though they bore a family name and thus belonged to the upper social stratum in Babylonian society, their profile appears more mercantile than priestly. ${ }^{96}$ Whereas the private life of prebendary families was turned towards the priestly in-group, ${ }^{97}$ Guzānu took a wife from a Judean family of merchants and the Ararrus of Babylon had contacts with people of non-Babylonian origin. The fact that they engaged in beer brewing and were connected to the wealthy business family of Egibi indicates that they were involved in business activities in Babylon. Finally, the Ararrus originated from Babylon rather than from Sippar. The marriage agreements of Kaššāya and Guzānu are the only certain attestation of the Ararrus in Sippar, whereas there are four or five separate documents from Babylon. This is noteworthy, because several families moved from Babylon to Sippar in the sixth century, including the Șāhit-ginês, a branch of the Ša-nāšišus, and the Arad-Nergals. Royal investments and the

92 See Tallqvist 1905, 16-17.

93 See PNA 2/II, 750-53.

94 Zadok 1977, 12, 20-21, 248.

95 Wunsch, personal communication. She suggests that the tablet probably originates from Babylon. Cf. Leichty et al. 1988, 121. According to C. B. F. Walker (in Leichty et al. 1988, xi-xiv), the tablet was acquired from a private person and it possibly originates from Babylon or Sippar.

96 Cf. Bloch 2014, 145. On the terms "mercantile" and "priestly," see footnote 21 above.

97 Still 2016. 
booming economy made Sippar attractive for these newcomers, some of whom achieved great success in their new hometown. Even though some members of these families were able to make their way into the priestly circles of Ebabbar, the community of newcomers was geared towards trading activities. ${ }^{98}$ It is much easier to fit the family of Guzānu into this mercantile community than into the old, established elite of Sippar and the priestly circles of Ebabbar.

Some of the witnesses with Babylonian names, patronymics, and family names can also be identified as members of the Sipparean mercantile community. The business profile of these people becomes apparent from the documents belonging to the archive of Marduk-rēmanni/Bēl-uballiț/Ṣāhit-ginê and its satellite archives. Marduk-rēmanni's family originated in Babylon but moved to Sippar in the sixth century, and Marduk-rēmanni became a member of the local trading community. At the same time, he succeeded in gaining a firm foothold in the priestly circles of Ebabbar, and his archive is an indispensable source of information on the life of these two distinct communities. ${ }^{99}$ Neither Marduk-rēmanni nor members of his family are present in the documents pertaining to the descendants of Arih, but they shared several common acquaintances. A witness of both marriage agreements, Nabû-iddin/Bānia/Pahhāru, was related to two business agents of the Șāhit-ginê family. ${ }^{100}$ Another link to the Șāhit-ginê family was Bānia/Bēl-nāṣir/Arad-Nergal. He belonged to a family which had moved from Babylon to Sippar at the same time as the Șāhit-ginês and had become part a of the Sipparean trading community. ${ }^{101}$ Furthermore, an interesting witness in the earlier marriage agreement is Šuzubu/ Zababa-ah-iddin/Ile'i-Marduk, who acted several times as a scribe in documents in Marduk-rēmanni's archive. ${ }^{102}$ Finally, a certain Guzānu/Kiribtu is a witness in a promissory note belonging to the archive of Marduk-rēmanni, and it is possible that this Guzānu was the groom of Kaššāya. ${ }^{103}$

Prosopographical data connects text no. 6 with the marriage agreements and the family of Kaššāya, even if Bēl-iddin/Amušê, the third witness of no. 6, is not attested in the marriage agreements. A direct link between the earlier marriage agreement no. 2 and text no. 6 is (Nabû-)Bān-zēri/Rīmūt-Bēl/Isinnayya, who witnessed both documents. Interestingly enough, he is the only witness of the marriage agreements to have held a prebend at the Ebabbar temple. ${ }^{104}$ The profiles of the lessee and guarantor in no. 6 indicate that the text originated in the same social setting as the five earlier documents. The lessor Rìmūt/Šamaš-zēr-ibni cannot be definitively identified in other extant docu-

98 On these families, see Waerzeggers 2014a, 45-49, 119-24.

99 Waerzeggers 2014a, esp. 15-30, 61-93, 113-25.

100 Waerzeggers 2014a, 81-82, 214; texts 8, 25.

101 Waerzeggers 2014a, 45-49.

102 Waerzeggers 2014a, texts $23,24,69,85,86,171$.

103 Waerzeggers 2014a, 214; text 39.

104 He held a baker's prebend; see Bongenaar 1997, 173. 
ments, but the lessee Šamaš-uballiț/Nādin/Bā?iru participated in a harrānu business venture with a member of the Ša-nāššsu family in BM 74469. ${ }^{105}$ The Ša-nāšišu family, which had also migrated to Sippar from Babylon, was a part of the Sipparean mercantile and priestly communities. ${ }^{106}$ Another member of this family, Bēl-ittannu/Šamaš-uballiț/Ša-nāšišu, acted as a guarantor in text no. 6 , a document which belongs to his private archive. ${ }^{107}$ Bēl-iddin/Amušê must have been familiar with these people and their businesses. It is likely that his father Amušê was the father of Kaššãya: the descendants of Arih and the lessee and guarantor of text no. 6 shared an interest in entrepreneurial activities, Amušê is a rare name in Babylonian sources, and a brother of Kaššāya could still have been alive 31 years after the marriage agreements were drafted. However, it is impossible to know if Bēl-iddin was the unnamed brother in the earlier marriage agreement. ${ }^{108}$

Prosopographical research shows that the descendants of Arih were closely connected with the community of merchants in the city of Sippar. As royal merchants, they traded with the Ebabbar temple, but only one of the witnesses in the marriage agreements was a priest holding a prebend. ${ }^{109}$ The family of the groom had a mercantile rather than a priestly profile, and the witnesses of the marriage agreements were predominantly royal merchants or belonged to families which participated in trading activities. The international character of Sipparean traders is also quite apparent in the texts, and people of both West Semitic and Babylonian origin were among the acquaintances of the Judean family. In this connection, it is important to note that some members of the Sipparean trading community participated in long-distance trade from Syria and the Levant to Babylonia. ${ }^{10}$ Accordingly, the family of Arih was rooted in two distinctively international realms of Babylonian society. On the one hand, they were part of the state apparatus as royal merchants, ${ }^{111}$ and, on the other hand, they were members of the multi-ethnic community of traders at the quay of Sippar.

105 Jursa 2005, $126+$ n. 968.

106 On the Ša-nāšišus, see Waerzeggers 2014a, 46, 72-74, 124-25.

107 The Ša-nāšišu B archive in Jursa 2005, 126-27.

108 Cf. Bloch 2014, 160-61.

109 Cf. Bloch 2014, 141.

110 Bongenaar 2000, 86; Waerzeggers 2014a, 85-89.

111 See Jursa 2015 on the multi-lingual and multi-ethnic character of the Babylonian state administration. 


\subsection{Identity, Integration, and Socioeconomic Status}

Analysis of the social network of the descendants of Arih shows that the Judean family had found its place among the community of merchants in Sippar. In the following discussion, I study how this is reflected in their identity and how deeply they were integrated into Babylonian society. These questions have been studied in detail by Bloch, ${ }^{112}$ and I thus limit my discussion to some new aspects and interpretations of the evidence.

The majority of the names borne by the descendants of Arih are Babylonian. ${ }^{113}$ Only two of his sons, Ahu-Yāma and Amušê, had distinctively Judean names. The names borne by the third generation are fully Babylonian, and three different gods - Bēl (Marduk), Nabû, and Šamaš - are referred to in the theophoric elements. At first sight, the naming practices of this Sipparean family are in stark contrast to the figures derived from the Judean communities in the countryside. A significantly higher number of identifiable Judeans in the Murašu archive bear Yahwistic names, and the same applies to Judeans in Yāhūdu and its surroundings. ${ }^{114}$ The descendants of Arih were certainly quite different from the Judeans in the countryside, but the available data is somewhat misleading as well. Judeans can be normally identified only on the basis of Yahwistic or other distinctly Judean names borne by them or their relatives. This skews the overall picture in favour of those who bore traditional Judean names.

The relationship between theophoric names and religious practice is complex, and a theophoric name devoted to a certain deity does not exclude its bearer's worship of other gods. Therefore, it cannot be argued that Ahu-Yāma revered Yahweh and Bēl-iddin worshipped Marduk. However, the readiness to use Babylonian theophoric names indicates that the descendants of Arih were at home in the religious environment of Babylonia. ${ }^{15}$ This is visible also in Kaššāya's and Guzānu's marriage agreements, in which Marduk, Zarpanitu, and Nabû were customarily invoked in the curse section. This is noteworthy in view of Kathleen Abraham's argument that the stipulations of a marriage agreement were negotiated by the parties and not dictated by the scribe. ${ }^{116}$ Accordingly, the invoking of Babylonian gods could not have been an abomination to the Judean family. Judean cultural-religious traditions are visible in the names of Ahu-Yāma and Amušê, but Yahweh's importance for the descendants of Arih remains unknown.

112 Bloch 2014, 127-35.

113 See Bloch 2014, 127-30.

114 On the Murašû archive, see Bickerman 1978, 15; Bloch 2014, 124-25. A similar picture arises when Bickerman's method is applied to the prosopographical data from Yāhūdu and its surroundings (see the prosopographical index in Pearce and Wunsch 2014, 257-300). See also Pearce 2015, 19-22, 29.

115 See Bloch 2014, 129-30.

116 Abraham 2015, 33-57. 
The names of the descendants of Arih reflect the environment they were living in. They were members of the Sipparean trading community and had people of Babylonian and foreign origin in their intimate circles. Close contact with Babylonians accelerated their integration and adoption of local naming practices. Their professional life as merchants naturally played a role in this process, but a desire to advance trade relations with the Ebabbar temple was hardly the main reason for it. ${ }^{117}$ Contact with Babylonians was not a decisive factor in the adoption of Babylonian names or culture, as the example of Ahīqam, son of Rapā-Yāma, from the village of Yāhūdu shows. This Judean was in close contact with Babylonians (CUSAS 28 14, 17, 18) and even traded in Babylon (CUSAS 28 44, 45), but he gave no Babylonian names to his sons. ${ }^{118}$ The nature and intensity of contact are important: collegial and friendship ties are often more influential than business relationships. ${ }^{19}$

Several aspects of Kaššāya’s marriage agreements exhibit a high level of integration into Babylonian society. These include her marriage into a Babylonian family, the Babylonian witnesses of the contract, and its conformity to the standard legal practices of its time. An interesting detail of the dowry is the Akkadian bed (gišná $a k-k a-d i-i-t u^{4}$ ), which stands out from the list of jewellery, furniture, and household utensils. Kaššāya is one of three brides in Neo-Babylonian sources who received such a bed as a part of their dowry. Another bride, Habašinnatu (Nbn 258), came from the Kāșir family and married into the Rabbanê family; the Akkadian bed was one of four beds given as a dowry. The family names confirm that the marriage was established between native Babylonians. A third bride, Tahê-[...], not only received an Akkadian bed but also an Akkadian table, according to the marriage agreement BMA 23 (= Dar 301). Both Tahê- $[\ldots]$ and her husband Pațmiustû were of Egyptian origin, ${ }^{120}$ which makes this case comparable to the marriage agreement of Kaššàya. Even though the appearance of an Akkadian bed is unknown, it must have been somehow different from the ordinary beds of the period. ${ }^{121}$ It is tempting to perceive the Akkadian bed as a device which these two immigrant families used to emphasise their integration into Babylonian society. ${ }^{122}$ The Akkadian bed was a product of their new homeland and thus loaded with symbolic value, not a mere piece of furniture.

117 Cf. Bloch 2014, 132.

118 See his family tree in Pearce and Wunsch 2014, 8.

119 This relates to the concept of tie strength in social network analysis. See Granovetter 1973.

120 Abraham 2015, 40-44; Hackl and Jursa 2015, 162-63, 165.

121 This is made clear in Nbn 258:8-9. In addition to the three dowries, an Akkadian bed is also included in a list of furniture and household utensils in Nbk 441:1.

122 Caroline Waerzeggers, personal communication. 
The previous observations about their integration, social networks, and status as royal merchants indicate that the descendants of Arih had a relatively good social standing in Sippar. Intuitively, one would like to suggest that professional merchants like the family of Arih were wealthy, but the scanty information on their possessions does not allow easy conclusions. First, the transactions of Basia, Marduka, and Amušê are silent on the profits which the brothers made from their trade. Only the marriage agreements reveal something about the wealth of the family, but, as noted above, the picture is somewhat unclear. The bride indeed received some jewellery for personal use and furniture and kitchen utensils for running the new household, but the dowry lacked any truly valuable items such as silver, real estate, or slaves. However, a modest dowry was not always indicative of financial constraints, and it cannot be reliably used to estimate the wealth of the bride's family. Given their profession, social networks, and success in marrying their daughter to a man from the Ararru family, the descendants of Arih belonged to the better-off in Babylonian society. ${ }^{123}$

\section{Other Judean Merchants in Babylonia}

In addition to the descendants of Arih, three other Judeans were involved in trading activities in Babylonia in the sixth century BCE. The documents concerning these people relate to long-distance trade, which helps to contextualise the transactions of the Judean royal merchants in Sippar. The earliest attestation of a Judean trader in Babylonia is dated in the fortieth year of Nebuchadnezzar II (21-IV-40 Nbk, 565 BCE). The document was written in Opis, which was an important hub of Babylonian foreign trade in the sixth century. Even though the town was located in north-east Babylonia on or near the Tigris, it also functioned as a station of Trans-Euphratian trade. ${ }^{124}$ In Nbk 361, a certain Aia-ahâ, son of Šani-Yāma, is a party in a court case concerning trade goods or capital (mēreštu) worth $2 \frac{1}{2}$ minas of silver. ${ }^{125}$ In Neo-Babylonian business documents, the word mèreštu refers to trade goods that were imported to Babylonia or to silver capital that was invested to acquire such goods. ${ }^{126}$ In the context of the present document, it seems likely that the dispute concerned the capital of

123 See Waerzeggers 2014b, 140; Abraham 2015, 45, 48.

124 Jursa 2010, 80-84, 120-21.

125 The document belongs to a group of legal texts written by Nabû-ahhē-iddin/Šulā/Egibi in Opis, where he - in close contact with people of prince Neriglissar's retinue - was pursuing a career of court scribe in the late reign of Nebuchadnezzar II. Nabû-ahhē-iddin does not seem to have had any personal interests in this court case, and, as van Driel suggests, the document must have ended up in the Egibi archive because Nabû-ahhē-iddin kept copies of some of the documents he wrote in Opis. See van Driel 1985/86, 54-59; Wunsch 2000, 98-102; Wunsch 2007, 237.

126 Oppenheim 1967, 239-40; van Driel 1986, 16-17 + n. 40; Tolini 2009, 249; Jursa 2010, 93 , $505-6$. 
a harrānu trading venture, which the investor Nabû-na?id had put at the disposal of his agents Aia-ahâ and Barūhi-il. ${ }^{127}$ Since the word mèreštu belongs to the terminology of long-distance trade and Opis was a starting point for such overland trading missions, it is reasonable to suggest that the venture of Aia-ahâ and Barūhi-il was directed towards an area outside Babylonia proper.

Two other documents on Judean merchants or business agents in Babylonia belong to the archive of the Sipparean trader Iššar-taribi, son of Bunene-ibni. ${ }^{128}$ Iššar-tarībi's business profile was rather unusual, as he was a non-institutional merchant taking part in long-distance trade. This is indicated by the fact that Opis and the Iranian town of Humadēsu are mentioned in his archive, the latter in a clear trade context. ${ }^{129}$ Ǐšar-taribi was a member of the trading community of Sippar ${ }^{130}$ and shared common acquaintances with the descendants of Arih. ${ }^{131}$ Another important feature of Iššar-taribi's archive is the great number of people with non-Babylonian names. ${ }^{132}$ This observation strengthens the view that Iššar-tarībi participated in long-distance trade, in which people of foreign origin played a central role.

The first document concerning Judeans in Iššar-taribii's archive was written in Sippar in the seventh year of Cambyses (26-X-7 Camb, 522 BCE). ${ }^{133}$ A certain Mannu-kī-Bānìtu, son of Bēl-ab-uṣur, sold a donkey to Iššar-tarībi. The contract defines that the donkey was delivered to Mannu-kī-Bānitu by a third man called Tagabi-Yāma in Humadēšu. ${ }^{134}$ As Weszeli points out, the scribe obviously made a mistake in the section concerning the delivery of the animal: the recipient of the donkey should naturally be its buyer, Iššar-tarībi. ${ }^{135}$ Humadēšu was not in the vicinity of Sippar, but it was located in Iran, near the site where Persepolis was later built. ${ }^{136}$ There must have been a special reason for a journey to Humadēšu, and in this case, long-distance trade appears to be the most probable explanation. Iššar-tarībi's archive makes it clear that its owner was a businessman, and the evidence of a businessman buying a pack animal in a foreign locality points strongly towards trading activities. ${ }^{137}$ Unfor-

127 On harrānu partnerships, see Jursa 2009, 53-68 and the literature cited there.

128 The texts in the archive of Iššar-taribi are dated to the second half of the sixth century BCE (8 Cyr-23 Dar). There is no thorough study of Iššar-taribi and his archive. For short overviews, see Bongenaar 2000, 89-90; Jursa 2005, 124; Jursa 2010, 220-21, 224-25; Waerzeggers 2014a, 86-89. On his contacts with Judeans, see Waerzeggers 2014b, 140.

129 Dar 149 and Weszeli 1996, no. 2, respectively. See Jursa 2010, 224-25.

130 Waerzeggers 2014a, 19-22, 86-89.

131 Nabû-iddin/Bānia/Pahhāru witnessed the marriage agreements of Kaššāya and Guzānu, and his nephew Nabû-iqišsa is a witness in a promissory note from Iššar-tarïbi’s archive (unpublished BM 74460; see Waerzeggers 2014a, 21 n. 33).

132 Il-hanan in Weszeli 1996, no. 2, and Barikia in Jursa and Weszeli 2000, 82-84, to name but a few. See Zadok 1977, 88, 122-23, respectively.

133 Weszeli 1996, no. 2.

134 On the name Tagabi-Yāma, see Zadok 1996, 727.

135 Weszeli 1996, 473.

136 Henkelman 2008, 338.

137 See Zadok 2002, 31; Jursa 2010, 225 + n. 1311. 
tunately, there is no way to know whether Tagabi-Yāma was a servant of the seller or buyer, or their colleague or acquaintance. However, judging from his Yahwistic name, he was a Judean - and a man involved in long-distance trade outside Babylonia proper.

In addition to Tagabi-Yāma, another Judean, son of Gamar-Yāma, is attested in the archive of Iššar-taribi. His name is broken. He witnessed a document concerning the sale of a Bactrian female slave, drafted in Sippar in the tenth year of Darius (18-II-10 Dar, 512 BCE). ${ }^{138}$ This sale contract emphasises the international nature of Iššar-taribi's social circles: none of the witnesses bore a family name, three of them had a non-Babylonian name or patronymic, ${ }^{139}$ and the Bactrian slave had alphabetic writing tattooed or burned on her neck. Tagabi-Yāma and the son of Gamar-Yāma lived in this world of traders, nonBabylonians, and speakers of Aramaic. It cannot be ascertained whether the son of Gamar-Yāma was a merchant himself, but his connection to the circles of Iššar-tarībi is suggestive of such a profile.

\section{Long-Distance Trade and Judean Merchants}

It is beyond doubt that some Judeans participated in Babylonian long-distance trade. Tagabi-Yāma's actions in Humadēšu, Iran took place in an obvious trading context, and all aspects of Aia-ahâ's court case suggest a connection to an overland trading mission. The son of Gamar-Yāma was not perhaps a merchant himself, but he also knew people who certainly participated in long-distance trade. In the case of the descendants of Arih, several features of their business activities are indicative of their participation in long-distance trade. Gold had to be imported to Babylonia, which means that the family had, at the very least, contacts with people who took part in the importation of the precious met al. Being stationed at Sippar, they were well positioned to either acquire gold from their local contacts or embark on trading missions along the Euphrates. As royal merchants, they belonged to the group of professional traders who undertook such missions to fulfil the needs of the palace, temples, and elite in Babylonia. Finally, people in their social circles in Sippar were involved in local and long-distance trading operations.

It is well known that people of foreign origin played a central role in Babylonian long-distance trade, and it is not surprising that Judeans participated in it as well. The commercial sphere of Babylonian society was open to immigrants, who had some advantages over their Babylonian peers when it came to long-distance trade. An important factor was their ability to reduce the transaction costs of trade. Existing networks and knowledge of local languages,

138 Jursa and Weszeli 2000, 82-84.

139 Zadok 2002, 31-32. 
products, and trading practices gave immigrants easier access to the markets in their native country. ${ }^{140}$

Judeans participated in Babylonian long-distance trade, and documented evidence shows that some of them travelled as far as Iran for the purpose of trading. There is no evidence that their trading missions reached Syria and the Levant, even though people in their surroundings participated in Trans-Euphratian trade. Judean merchants are attested in Opis and Sippar, which were important stations of trading missions to the west. The descendants of Arih were deeply integrated into the Sipparean trading community, some members of which were involved in trade from Syria and the Levant to Babylonia. Therefore, it is possible that some Judean merchants - such as the descendants of Arih and their colleagues - also travelled to the Levant, perhaps as far as Judah, for the purpose of trade. ${ }^{141}$ This would also make them good candidates for having been intermediaries between Judeans living in Judah and Babylonia. News and messages easily travel along with trade goods over long distances.

\section{Bibliography}

Abraham, K. 2004. Business and Politics Under the Persian Empire: The Financial Dealings of Marduk-nāșir-apli of the House of Egibi [521-487 B.C.E.]. Bethesda, MD: CDL.

Abraham, K. 2005/2006. West Semitic and Judean Brides in Cuneiform Sources from the Sixth Century BCE: New Evidence from a Marriage Contract from Āl-Yahudu. Archiv für Orientforschung 51: 198-219.

Abraham, K. 2015. Negotiating Marriage in Multicultural Babylonia: An Example from the Judean Community in Āl-Yāhūdu. In: Stökl, J. and Waerzeggers, C. (eds.), Exile and Return: The Babylonian Context. Beihefte zur Zeitschrift für die alttestamentliche Wissenschaft 478. Berlin: De Gruyter, 33-57.

Bickerman, E. 1978. The Generation of Ezra and Nehemiah. Proceedings of the American Academy for Jewish Research 45: 1-28.

Bloch, Y. 2014. Judeans in Sippar and Susa during the First Century of the Babylonian Exile: Assimilation and Perseverance under Neo-Babylonian and Achaemenid Rule. Journal of Ancient Near Eastern History 1: 119-172.

Bongenaar, A. 1997. The Neo-Babylonian Ebabbar Temple at Sippar: Its Administration and Its Prosopography, Publications de l'Institut Historique-Archeologique Neerlandais de Stamboul 80. Istanbul: Nederlands Historisch-Archaeologisch Instituut.

Bongenaar, A. 2000. Private Archives in Neo-Babylonian Sippar and their Institutional Connections. In: Bongenaar, A. (ed.), Interdependency of Institutions and Private Entrepreneurs: Proceedings of the Second MOS Symposium (Leiden 1998). Publications de l'Institut HistoriqueArcheologique Neerlandais de Stamboul 87. Istanbul: Nederlands Historisch-Archaeologisch Instituut, 73-94.

Cameron, G.G. 1948. Persepolis Treasury Tablets. Oriental Institute Publications 65. Chicago: The University of Chicago Press.

140 On brokers in cross-cultural trade, see Curtin 1984. On immigration and its impact on modern international trade, see Gould 1994, 302-16; Rauch and Trindade 2002: 116-30; Law et al. 2013, 582-606.

141 See Waerzeggers 2014b, 132. 
Coogan, M. 1973. Patterns in Jewish Personal Names in the Babylonian Diaspora. Journal for the study of Judaism in the Persian, Hellenistic and Roman period 4: 183-191.

Curtin, P. 1984. Cross-Cultural Trade in World History. Cambridge: Cambridge University Press.

Dandamayev, M. 1971. Die Rolle des tamkārum in Babylonien im 2. und 1. Jahrtausend v. u. Z. In: Klengel, H. (ed.), Beiträge zur sozialen Structur des alten Vorderasien. Schriften zur Geschichte und Kultur des Alten Orients 1. Berlin: Akademie-Verlag, 70-78.

Dandamayev, M. 1995. The Neo-Babylonian tamkārū. In: Zevit, Z., Gitin, S., and Sokoloff M. (eds.), Solving Riddles and Untying Knots: Biblical, Epigraphic, and Semitic Studies in Honor of Jonas C. Greenfield. Winona Lake, IN: Eisenbrauns, 523-530.

Da Riva, R. 2013. Nebuchadnezzar II's Prism (EŞ 7834): A New Edition. Zeitschrift für Assyriologie 103: 196-229.

Dhorme, E. 1928. Les tablettes babyloniennes de Neirab. Revue d'assyriologie et d'archeologie orientale 25: 53-82.

Dignas, B. and Winter E. 2007. Rome and Persia in Late Antiquity: Neighbours and Rivals. Cambrigde: Cambridge University Press.

van Driel, G. 1985/86. The Rise of the House of Egibi: Nabû-abhē-iddina. Jaarbericht van het Vooraziatisch-Egyptisch Genotschaap 'Ex Oriente Lux' 29: 50-67.

van Driel, G. 1986. Neo-Babylonian Texts from the Louvre. Bibliotheca orientalis. Leiden 43: 6-20.

Elat, M. 1987. Der tamkäru im neuassyrischen Reich. Journal of the economic and social history of the Orient 30: 233-254.

Gould, D. 1994. Immigrant Links to the Home Country: Empirical Implications for U.S. Bilateral Trade Flows. The Review of Economics \& Statistics 76: 302-316.

Granovetter, M. 1973. The Strength of Weak Ties. American Journal of Sociology 78: 1360-1380.

Graslin-Thomé, L. 2009. Les échanges à longue distance en Mésopotamie au Ir millénaire: Une approche économique. Orient \& Méditerranée 5. Paris: De Boccard.

Graslin-Thomé, L. 2014. Les marchands mésopotamiens et la théorie des jeux. In: Csabai, Z. (ed.), Studies in Economic and Social History of the Ancient Near East in Memory of Péter Vargyas. Ancient Near Eastern and Mediterranean Studies 2. Budapest: L'Harmattan, 603-627.

Hackl, J. and Jursa, M. 2015. Egyptians in Babylonia in the Neo-Babylonian and Achaemenid Periods. In: Stökl, J. and Waerzeggers, C. (eds.), Exile and Return: The Babylonian Context. Beihefte zur Zeitschrift für die alttestamentliche Wissenschaft 478. Berlin: De Gruyter, 157-180.

Heltzer, M. 2006. The 'Royal Merchants' (tamkārū (ša) šarri) in Neo-Babylonian and Achaemenid Times and the West Semites among them. Ugarit-Forschungen 38: 347-351.

Henkelman, W. 2008. The Other Gods Who Are: Studies in Elamite-Iranian Acculturation Based on the Persepolis Fortification Texts. Achaemenid History 14. Leiden: Nederlands Instituut voor het Nabije Oosten.

Hezser, C. 2011. Jewish Travel in Antiquity, Texte und Studien zum antiken Judentum 144. Tübingen: Mohr Siebeck.

Jakob-Rost, L. 1970. Urkunden des 7. Jahrhunderts v. u. Z. aus Babylon. Forschungen und Berichte 12: 49-60.

Joannès, F. 1982. Textes économiques de la Babylonie récente. Étude des textes de TBER 6. Paris: Éditions Recherche sur les civilisations.

Joannès, F. 1992. Inventaire d'un cabaret. Nouvelles assyriologiques brèves et utilitaires 1992/64.

Joannès, F. 1999. Structures et opérations commerciales en Babylonie à l'époque néo-babylonienne: In: Dercksen, J. (ed.), Trade and Finance in Ancient Mesopotamia: Proceedings of the First MOS Symposium (Leiden 1997). Publications de l'Institut Historique-Archeologique Neerlandais de Stamboul 84. Istanbul: Nederlands Historisch-Archaeologisch Instituut, 175-194.

Jursa, M. 1998. Der Tempelzehnt in Babylonien vom siebenten bis zum dritten Jahrhundert v. Chr. Alter Orient und Altes Testament 254. Münster: Ugarit-Verlag.

Jursa, M. 2001. Kollationen. Nouvelles assyriologiques brèves et utilitaires 2001/102.

Jursa, M. 2004a. Grundzüge der Wirtschaftsformen Babyloniens im ersten Jahrtausend v. Chr. In: Rollinger, R. and Ulf, C. (eds.), Commerce and Monetary Systems in the Ancient World: Means of Transmission and Cultural Interaction: Proceedings of the Fifth Annual Symposium of the Assyrian and Babylonian Intellectual Heritage Project, Held in Innsbruck, Austria, October 3rd-8th, 2002. Melammu Symposia 5. Stuttgart: Franz Steiner, 115-136. 
Jursa, M. 2004b. Neubabylonische Texte. In: Janowski, B. and Wilhelm, G. (eds.): Texte zum Rechtsund Wirtschaftsleben. Texte aus der Umwelt des Alten Testaments NF 1. Gütersloh: Gütersloher Verlagshaus, 89-110.

Jursa, M. 2005. Neo-Babylonian Legal and Administrative Documents: Typology, Contents and Archives. Guides to the Mesopotamian Textual Record 1. Münster: Ugarit-Verlag.

Jursa, M. 2006. Review of Neo-Babylonian Texts in the Oriental Institute, by David B. Weisberg. Journal of the American Oriental Society 126: 452-458.

Jursa, M. 2007. Eine Familie von Königskaufleuten judäischer Herkunft. Nouvelles assyriologiques brèves et utilitaires 2007/22.

Jursa, M. 2009. Business Companies in Babylonia in the First Millennium BC: Structure, Economic Strategies, Social Setting. In: Wissa, M. (ed.), The Knowledge Economy and Technological Capabilities: Egypt, the Near East and the Mediterranean, 2nd Millennium B.C. - 1st Millennium A.D. Aula Orientalis Supplementa 26. Sabadell: AUSA, 53-68.

Jursa, M. 2010. Aspects of the Economic History of Babylonia in the First Millennium BC: Economic Geography, Economic Mentalities, Agriculture, the Use of Money and the Problem of Economic Growth. With contributions by J. Hackl, B. Janković, K. Kleber, E. E. Payne, C. Waerzeggers, and M. Weszeli. Alter Orient und Altes Testament 377. Münster: Ugarit-Verlag.

Jursa, M. 2015. Families, Officialdom, and Families of Royal Officials in Chaldean and Achaemenid Babylonia. In: Archi, A. (ed.), Tradition and Innovation in the Ancient Near East: Proceedings of the 57th Rencontre Assyriologique Internationale at Rome, 4-8 July 2011. Winona Lake, IN: Eisenbrauns, 597-606.

Jursa, M. and Baker, H.D. 2011. Sippar. A. II. Im 1. Jahrtausend. Reallexikon der Assyriologie und Vorderasiatischen Archäologie 12, 533-537.

Jursa M. and Weszeli, M. 2000. Der 'Zahn' des Schreibers: Ein aramäischer Buchstabenname in akkadischer Transkription. Zeitschrift für Assyriologie 90: 78-84.

Law, D. Genç, M. and Bryant, J. 2013. Trade, Diaspora and Migration to New Zealand. The World Economy 36: 582-606.

Leichty, E., Finkelstein, J. and Walker, C. 1988. Tablets from Sippar 3, Catalogue of the Babylonian Tablets in the British Museum 8. London: British Museum.

Leichty, E. and Grayson, A. 1987. Tablets from Sippar 2. Catalogue of the Babylonian Tablets in the British Museum 7. London: British Museum.

Lorenz, J. 2005/2006. 20, 30, 40 Schekel. Archiv für Orientforschung 51: 248-251.

MacGinnis, J. 1994. The Royal Establishment at Sippar in the 6th Century BC. Zeitschrift für Assyriologie 84: 198-219.

MacGinnis, J. 1995. Letter Orders from Sippar and the Administration of the Ebabbara in the Late-Babylonian Period. Poznań: Bonami.

Nielsen J. 2011. Sons and Descendants: A Social History of Kin Groups and Family Names in the Early Neo-Babylonian Period, 747-626 BC. Culture and History of the Ancient Near East 43. Leiden: Brill.

Nielsen, J. 2015. Personal Names in Early Neo-Babylonian Legal and Administrative Tablets, 747-626 B.C.E. Nisaba 29. Winona Lake, IN: Eisenbrauns.

Nissinen, M. 2014. Assyria. In: Niehr, H. (ed.), The Aramaeans in Ancient Syria. Handbuch der Orientalistik 106. Leiden: Brill, 273-296.

Oelsner, J., Wells, B. and Wunsch, C., 2003. Neo-Babylonian Period. In: Westbrook, R. (ed.), A History of Ancient Near Eastern Law 2. Handbuch der Orientalistik 72/2. Leiden: Brill., 911-974.

Oppenheim, A. 1967. Essay on Overland Trade in the First Millennium B.C. Journal of cuneiform studies 21: 236-254.

Oppenheimer, A. 2005. Between Rome and Babylon: Studies in Jewish Leadership and Society. Texte und Studien zum antiken Judentum 108. Tübingen: Mohr Siebeck.

Parker, B. 1961. Administrative Tablets from the North-West Palace, Nimrud. Iraq 23: 15-67.

Pearce, L. and Wunsch C. 2014. Documents of Judean Exiles and West Semites in Babylonia in the Collection of David Sofer. Cornell University Studies in Assyriology and Sumerology 28. Bethesda, MD: CDL. 
Pearce, L. 2015. Identifying Judeans and Judean Identity in the Babylonian Evidence. In: Stökl, J. and Waerzeggers, C. (eds.), Exile and Return: The Babylonian Context. Beihefte zur Zeitschrift für die alttestamentliche Wissenschaft 478. Berlin: De Gruyter, 7-32.

Pedersén, O. 2005a. Archive und Bibliotheken in Babylon: Die Tontafeln der Grabung Robert Koldeweys 1899-1917. Abhandlungen der Deutschen Orientgesellschaft 25. Saarbrücken: Saarländische Druckerei und Verlag.

Pedersén, O. 2005b. Foreign Professionals in Babylon: Evidence from the Archive in the Palace of Nebuchadnezzar II. In: van Soldt, W., Kalvelagen, R. and Katz, D. (eds.), Ethnicity in Ancient Mesopotamia: Papers Read at the 48th Rencontre Assyriologique Internationale, Leiden, 1-4 July 2002. Publications de l'Institut Historique-Archeologique Neerlandais de Stamboul 102. Leiden: Nederlands Instituut voor het Nabije Oosten, 267-272.

Pinches, P.G. 1892. Old Persian Names in Babylonian Contracts. Hebraica 8: 134-135.

Radner, K. 1999. Traders in the Neo-Assyrian Period. In: Dercksen, J. (ed.), Trade and Finance in Ancient Mesopotamia: Proceedings of the First MOS Symposium (Leiden 1997). Publications de l'Institut Historique-Archeologique Neerlandais de Stamboul 84. Istanbul: Nederlands Historisch-Archaeologisch Instituut, 101-126.

Radner, K. and Baker, H. (eds.). 1998-2011. The Prosopography of the Neo-Assyrian Empire (PNA). Helsinki: The Neo-Assyrian Text Corpus Project.

Rauch, J. and Trindade, V. 2002. Ethnic Chinese Networks in International Trade. The Review of Economics \& Statistics 84: 116-130.

Roth, M. 1988. 'She Will Die By the Iron Dagger': Adultery and Neo-Babylonian Marriage. Journal of the economic and social history of the Orient 31: 186-206.

Roth, M. 1989. Babylonian Marriage Agreements: 7th-3rd Centuries B.C. Alter Orient und Altes Testament 222. Kevelaer: Butzon \& Bercker.

Roth, M. 1989/1990. The Material Composition of the Neo-Babylonian Dowry. Archiv für Orientforschung 36-37: 1-55.

Roth, M. 1991. The Dowries of the Women of the Itti-Marduk-balāțu Family. Journal of the American Oriental Society 111: 19-37.

von Soden, W. 1969. Grundriss der akkadischen Grammatik samt Ergänzungsheft zum Grundriss der akkadischen Grammatik. Analecta orientalia 33/47. Rome: Pontificium Institutum Biblicum.

Still, B. 2016. The Social World of the Babylonian Priest. PhD diss., Leiden University.

Stolper, M. 1976. A Note on Yahwistic Personal Names in the Murašû Texts. Bulletin of the American Schools of Oriental Research 222: 25-28.

Stolper, M. 1985. Entrepreneurs and Empire: The Murašû Archive, the Murašû Firm, and the Persian Rule in Babylonia. Publications de l'Institut Historique-Archeologique Neerlandais de Stamboul 54. Istanbul: Nederlands Historisch-Archaeologisch Instituut.

Streck, M. 2011.Das Onomastikon der Beamten am neubabylonischen Ebabbar-Tempel in Sippar. Zeitschrift für Assyriologie 91: 110-119.

Tallqvist, K., 1905. Neubabylonisches Namenbuch zu den Geschäftsurkunden aus der Zeit des Šamaššumukîn bis Xerxes, ASSF 32/2. Helsinki: Societas Scientiarum Fennica.

Thureau-Dangin, F. 1922. Notes assyriologiques. Revue d'assyriologie et d'archéologie orientale 19.

Tolini, G. 2009. Les repas du Grand Roi en Babylonie: Cambyse et le palais d'Abanu. In: Faivre, X., Lion, B. and Michel, C. (eds.), Et il y eut un esprit dans l'Homme: Jean Bottéro et la Mésopotamie. Travaux de la Maison René-Ginouvès 6. Paris: De Boccard, 237-254.

Tolini, G. 2013. The Economic Activities of Ishunnatu, a Slave Woman of the Egibi Family. REFEMA. http://refema.hypotheses.org/766.

Tolini, G. 2015. From Syria to Babylon and Back: The Neirab Archive. In: Stökl, J. and Waerzeggers, C. (eds.), Exile and Return: The Babylonian Context, Beihefte zur Zeitschrift für die alttestamentliche Wissenschaft 478. Berlin: De Gruyter, 58-93.

Utas, B. 1993. Byzantium Seen from Sasanian Iran. In: Rydén, L. and Rosenqvist, J. (eds.), Aspects of Late Antiquity and Early Byzantium: Papers Read at a Colloquium Held at the Swedish Research Institute in Istanbul 31 May - 5 June 1992. Swedish Research Institute in Istanbul Transactions 4. Stockholm: Swedish Research Institute in Istanbul, 21-30. 
Waerzeggers, C. 2014a. Marduk-rēmanni: Local Networks and Imperial Politics in Achaemenid Babylonia. Orientalia Lovaniensia analecta 233. Leuven: Peeters.

Waerzeggers, C. 2014b. Locating Contact in the Babylonian Exile: Some Reflections on Tracing Judean-Babylonian Encounters in Cuneiform Texts. In: Gabbay, U. and Secunda, S: (eds.), Encounters by the Rivers of Babylon: Scholarly Conversations between Jews, Iranians and Babylonians in Antiquity. Texte und Studien zum antiken Judentum 160. Tübingen: Mohr Siebeck, 131-146.

Waerzeggers, C. 2015. Review article of Documents of Judean Exiles and West Semites in Babylonia in the Collection of David Sofer, by Laurie E. Pearce and Cornelia Wunsch. Strata 33: 179-194.

Waerzeggers, C. 2016. What Do Names Not Tell Us about Social Realities? The Issue of the 'Family-Name-Bearing Elites' versus the 'Non-Family-Name-Bearing Others' (paper presented at the Babylonian Name and Name-Giving conference, Leuven, 8-9 February 2016).

Weidner, E. F. 1939. Jojachin, König von Juda, in Babylonischen Keilschrifttexten. In: Mélanges syriens offerts à Monsieur René Dussaud par ses amis et ses élèves 2, Bibliothèque archéologique et historique 30. Paris: Geuthner, 923-935.

Weszeli, M. 1996. Eseleien. Wiener Zeitschrift für die Kunde des Morgenlandes 86: 461-478.

Woods, C. 2005. On the Euphrates. Zeitschrift für Assyriologie 95: 7-45.

Wunsch, C. 1993. Die Urkunden des babylonischen Geschäftsmannes Iddin-Marduk: Zum Handel mit Naturalien im 6. Jahrhundert v. Chr. Groningen: STYX.

Wunsch, C. 2000. Neubabylonische Geschäftsleute und ihre Beziehungen zu Palast-und Tempelverwaltungen: Das Beispiel der Familie Egibi. In: Bongenaar, A. (ed.), Interdependency of Institutions and Private Entrepreneurs: Proceedings of the Second MOS Symposium (Leiden 1998). Publications de l'Institut Historique-Archeologique Neerlandais de Stamboul 87. Istanbul: Nederlands Historisch-Archaeologisch Instituut, 95-118.

Wunsch, C. 2003. Urkunden zum Ehe-, Vermögens- und Erbrecht aus verschiedenen neubabylonischen Archiven. Babylonische Archive 2. Dresden: ISLET.

Wunsch, C. 2007. The Egibi Family. In: Leick, G. (ed.), The Babylonian World. New York: Routledge, 236-247.

Wunsch, C. 2014. Babylonische Familiennamen. In: Krebernik, M. and Neumann, H. (eds.), Babylonien und seine Nachbarn in neu- und spätbabylonischer Zeit: Wissenschaftliches Kolloquium aus Anlass des 75. Geburtstags von Joachim Oelsner, Jena, 2. und 3. März 2007. Alter Orient und Altes Testament 369. Münster: Ugarit-Verlag, 289-314.

Zadok, R. 1976. On the Connections between Iran and Babylonia in the Sixth Century B.C. Iran 14: 61-78.

Zadok, R. 1977. On West Semites in Babylonia during the Chaldean and Achaemenian Periods: An Onomastic Study. Jerusalem: Wanaarta.

Zadok, R. 1979. The Jews in Babylonia during the Chaldean and Achaemenian Periods according to the Babylonian Sources. Studies in the History of the Jewish People and the Land of Israel Monograph Series 3. Haifa: The University of Haifa.

Zadok, R. 1996. Notes on Syro-Palestinian History, Toponymy and Anthroponymy. UgaritForschungen 28: 721-749.

Zadok, R. 2002. The Earliest Diaspora: Israelites and Judeans in Pre-Hellenistic Mesopotamia. Publications of the Diaspora Research Institute 151. Tel Aviv: Tel Aviv University.

Zadok, R. 2004. Israelites, Judeans and Iranians in Mesopotamia and Adjacent Regions. In: Ellens, J. et al (eds.), God's Word for Our World: Theological and Cultural Studies in Honor of Simon John De Vries 2. JSOTSup 389. London: T\&T Clark, 98-127.

Zadok, R. 2015. Yamu-iziri the Summoner of Yahūdu and Aramaic Linguistic Interference. Nouvelles assyriologiques brèves et utilitaires 2015/86.

Zawadzki, S. 1990. Great Families of Sippar during the Chaldean and Early Persian Periods (626$482 \mathrm{BC}$ ). Revue d'assyriologie et d'archeologie orientale 84: 17-25.

Zawadzki, S. 2010. Garments in Non-Cultic Context (Neo-Babylonian Period). In: Michel, C. and Nosch, M. (eds.), Textile Terminologies in the Ancient Near East and Mediterranean from the Third to the First Millennia BC. Ancient Textiles 8. Oxford: Oxbow, 409-429. 